\title{
On the capability of IASI measurements to inform about CO surface emissions
}

\author{
A. Fortems-Cheiney ${ }^{1}$, F. Chevallier ${ }^{1}$, I. Pison ${ }^{1}$, P. Bousquet ${ }^{1}$, C. Carouge $^{1, *}$, C. Clerbaux ${ }^{2}$, P.-F. Coheur ${ }^{3}$, M. George ${ }^{2}$, \\ D. Hurtmans ${ }^{3}$, and S. Szopa ${ }^{1}$ \\ ${ }^{1}$ Laboratoire des Sciences du Climat et de l'Environnement, CEA-CNRS-UVSQ, Gif-sur-Yvette, France \\ ${ }^{2}$ UPMC Univ Paris 06, CNRS UMR8190, LATMOS/IPSL, Paris, France \\ ${ }^{3}$ Spectroscopie de l'atmosphère, Chimie Quantique et Photophysique, Université Libre de Bruxelles, Brussels, Belgium \\ * now at: Division of Engineering and Applied Sciences, Harvard University, Cambridge, Massachusetts, USA
}

Received: 20 February 2009 - Published in Atmos. Chem. Phys. Discuss.: 20 March 2009

Revised: 7 October 2009 - Accepted: 14 October 2009 - Published: 16 November 2009

\begin{abstract}
Between July and November 2008, simultaneous observations were conducted by several orbiting instruments that monitor carbon monoxide in the atmosphere, among them the Infrared Atmospheric Sounding Instrument (IASI) and Measurements Of Pollution In The Troposphere (MOPITT). In this paper, the concentration retrievals at about $700 \mathrm{hPa}$ from these two instruments are successively used in a variational Bayesian system to infer the global distribution of $\mathrm{CO}$ emissions. Starting from a global emission budget of $479 \mathrm{Tg}$ for the considered period, the posterior estimate of $\mathrm{CO}$ emissions using IASI retrievals gives a total of $643 \mathrm{Tg}$, which is in close agreement with the budget calculated with version 3 of the MOPITT data $(649 \mathrm{Tg})$. The regional totals are also broadly consistent between the two inversions. Even though our theoretical error budget indicates that IASI constrains the emissions slightly less than MOPITT, because of lesser sensitivity in the lower troposphere, these first results indicate that IASI may play a major role in the quantification of the emissions of CO.
\end{abstract}

\section{Introduction}

The launch of a weather satellite, like METOP, generates new information flows about the atmosphere and the Earth surface with applications beyond Numerical Weather Prediction. The exploitation of such data usually leads to feeding them to data assimilation systems, where they co-

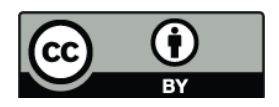

Correspondence to: F. Chevallier (frederic.chevallier@1sce.ipsl.fr) exist with other data of different origin (Hollingsworth et al., 2008). Ensuring the consistency of these systems in spite of the heterogeneous data flows is an important challenge for the satellite products since their definition varies for each instrument (Rodgers et al., 2003). Since the beginning of this century, several instruments have provided information about the atmospheric concentrations of carbon monoxide $\mathrm{CO}$, a key molecule to inform about the impact of human activities on the evolution of the composition of the atmosphere: MOPITT (Deeter et al., 2003), Atmospheric Chemistry Experiment-FTS (ACE-FTS) (Clerbaux et al., 2005), Tropospheric Emission Spectrometer (TES) (Luo et al., 2007), SCanning Imaging Absorption spectroMeter for Atmospheric ChartograpHY (SCIAMACHY) (Buchwitz et al., 2007) and IASI. Many subjective choices may induce inconsistencies (or biases) between these high-level products, like for the selection of the auxiliary datasets that help the concentration retrievals. This may explain why the estimation of the surface emissions of $\mathrm{CO}$, which is a major application of these data, has actually been limited to MOPITT so far (Arellano et al., 2004; Pétron et al., 2004; Allen et al., 2004; Heald et al., 2004; Pfister et al., 2004; Turquety et al., 2007; Clerbaux et al., 2008; Chevallier et al., 2009).

In this paper, we compare the inversion of $\mathrm{CO}$ emissions from MOPITT concentration retrievals and from IASI retrievals at global scale for a five-month period (from 1 July 2008 until 30 November 2008) with the aim of evaluating the consistency of the two products in such an application. $\mathrm{CO}$ emissions are retrieved at resolution $2.5^{\circ}$ in latitude and $3.75^{\circ}$ in longitude from instantaneous satellite data. Our approach is based on the variational inversion system of Chevallier et al. (2005), then implemented

Published by Copernicus Publications on behalf of the European Geosciences Union. 


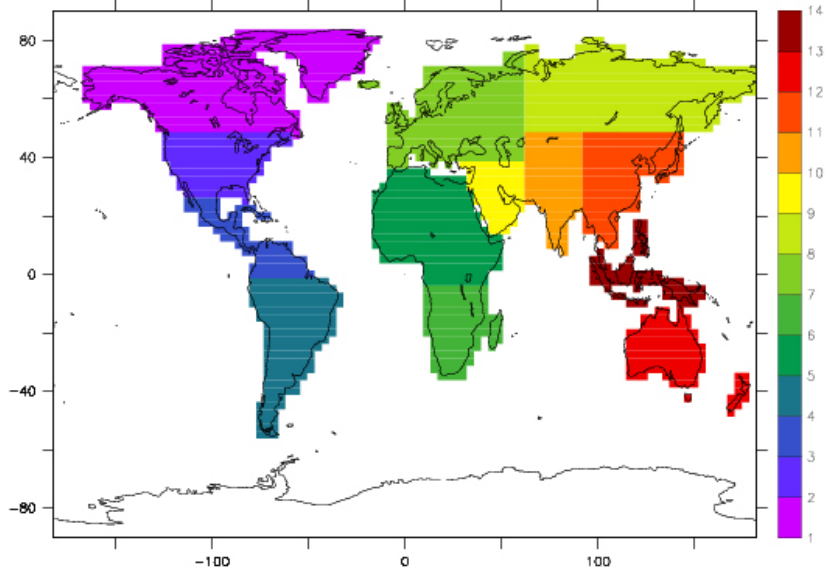

Fig. 1. Partition of the continents into 13 regions ( $1=$ North American Boreal, 2=USA, 3=South American Tropical, 4=South American Temperate, 5=Northern Africa, 6=Southern Africa, 7=Europe, 8=Eurasian Boreal, 9=Middle East, 10=South Asia, 11=South East Asia, 12=Australia, 13=Indonesia). This partition is used to synthesize the results of the grid-point inversion.

by a simplified chemistry module (Chevallier et al., 2009). This multi-species system includes the simplified chemistrytransport model (CTM) LMDz-SACS and its adjoint (Pison et al., 2009), optimizing the four main reactive species of the methane oxidation chain $\left(\mathrm{CH}_{4}, \mathrm{CO}\right.$, formaldehyde $\mathrm{HCHO}$ and $\mathrm{OH})$. Data and methods are described in the next section. The results are shown in Sect. 2.4 and discussed in the last section.

\section{Method and data}

\subsection{Inversion system}

The data assimilation system follows the work initiated by Chevallier et al. (2005) for $\mathrm{CO}_{2}$. As described in Chevallier et al. (2009), it seeks an optimal solution for global CO sources that is statistically consistent, in a Bayesian sense, with both the observed atmospheric concentrations and the available a priori information about the sources. The solution is found by the iterative minimization of a cost function $J$ defined as:

$J(\mathbf{x})=\left(\mathbf{x}-\mathbf{x}_{b}\right)^{T} \mathbf{B}^{-1}\left(\mathbf{x}-\mathbf{x}_{b}\right)+(\mathcal{H}(\mathbf{x})-\mathbf{y})^{T} \mathbf{R}^{-1}(\mathcal{H}(\mathbf{x})-\mathbf{y})$

$\mathcal{H}$ is the CTM LMDz-SACS described in the next section coupled with the averaging kernels of the satellite retrievals. $\mathbf{x}_{b}$ are the prior fluxes described in Sect. 2.3 with error statistics defined by the covariance matrix B. $\mathbf{y}$ are the observations of Section 2.4, the error statistics of which are represented by the covariance matrix $\mathbf{R}$. The state vector $\mathbf{x}$ consists of the following variables:
- the global $\mathrm{CO}, \mathrm{CH}_{4}, \mathrm{HCHO}$ and methylchloroform $\left(\mathrm{CH}_{3} \mathrm{CCl}_{3}, \mathrm{MCF}\right)$ emissions at an 8-day and $3.75^{\circ}$ $\times 2.75^{\circ}$ resolution,

- the 3-D-atmospheric source of HCHO from chemical oxydation of volatile organic compounds (VOC) and $\mathrm{CH}_{4}$ at the same space-time resolution,

- the $\mathrm{OH}$ atmospheric concentrations at the same spacetime resolution, except that only four degrees of freedom in latitude are actually kept by lack of MCF observations (Bousquet et al., 2005),

- the 3-D initial conditions of $\mathrm{CO}, \mathrm{CH}_{4}, \mathrm{HCHO}$ and MCF.

In this study, the June-November 2008 period is processed at once. However, the first month (June) will not be considered in the following because the inversion system hardly distinguishes errors in the fluxes from errors in initial concentrations for the first couple of weeks.

The M1QN3 limited-memory quasi-Newton software developed by Gilbert and Lemaréchal (1989) is our minimizer. Fifteen iterations are needed to reduce the norm of the gradient of $J$ by a 20 -fold factor.

This inversion system follows statistical principles and a full probability distribution function (pdf) of the posterior $\mathrm{CO}$ emissions could in principle be inferred. With Gaussian prior and Gaussian observation uncertainties (fully described by $\mathbf{B}$ and $\mathbf{R}$ ), the posterior pdf follows a multivariate Gaussian law. To limit the computational burden, the inversion system focuses on the solution with the largest probability. However, the width of the pdf is an important indicator of the reliability of the inferred emissions. Our approach for determining the posterior uncertainty consists in performing an ensemble of inversions (Chevallier et al., 2007). The members of the ensemble differ by the prior emissions and by the observations: the ensemble of prior emissions follows the error statistics given by $\mathbf{B}$ and the ensemble of observations follows the statistics given by $\mathbf{R}$. Doing that, the ensemble of inverted emissions follows the theoretical posterior error statistics (see Sect. 3.1).

\subsection{Chemistry-transport model}

The global 3-D CTM used in this study is LMDZ-SACS (Chevallier et al., 2005; Pison et al., 2009). LMDZ is version 4 of the general circulation model developed at Laboratoire de Météorologie Dynamique (Hourdin et al., 2007). It is run here at global $3.75^{\circ} \times 2.75^{\circ}$ resolution, nudged towards the winds analysed by the European Centre for MediumRange Weather Forecasts. SACS is the Simplified Atmospheric Chemistry System, which has been conceived as a simplification of the INCA scheme of Hauglustaine et al. (2004) and Folberth et al. (2006). As described by Pison et al. (2009), SACS aims to represent the oxydation chain of methane by solving the chemical interaction between a limited set of four species: $\mathrm{CO}, \mathrm{CH}_{4}, \mathrm{HCHO}$ and $\mathrm{OH}$. The main 


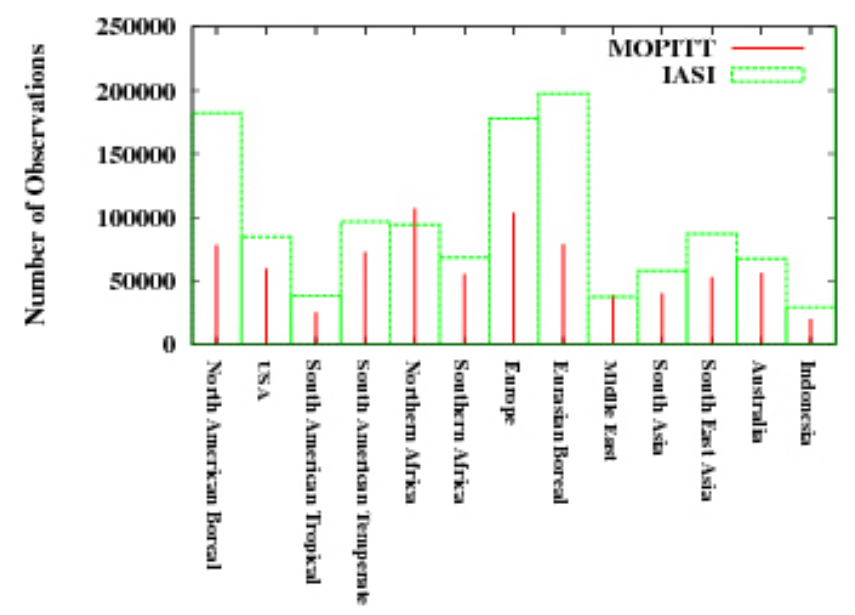

Fig. 2. The number of "super observations" for IASI and for MOPITT in each of the regions of Fig. 1.

assumption is to model only the production and the loss of $\mathrm{CH}_{4}, \mathrm{HCHO}, \mathrm{CO}$ and $\mathrm{H}_{2}$ and to consider all other reactions as instantaneous. In order to save computing time in the iterative inversion system, LMDZ-SACS uses a number of fields pre-computed from LMDZ-INCA for the transport (e.g., atmospheric mass fluxes) and for the chemistry (e.g., reaction yields).

\subsection{Prior emissions}

The prior information provided to the inversion system mainly combines two datasets: version 3 of the Emission Database for Global Atmospheric Research (EDGAR3) inventory valid for 1995 for the fossil fuel emissions (Olivier and Berdowski , 2001) and version 2 of the Global Fire and Emission database (GFED-v2; Van der Werf et al., 2006) valid for 2006 for biomass burning. No effort is made here to adapt the 1995 EDGAR3 inventory or the 2006 GFED-v2 data to year 2008 in the prior (the adaptation is done by the inversion system based on the concentration observations). It should be reminded that since 1995 or even 2000, global economic growth, in particular in Asia, has modified the amplitude of the fossil fuel emissions (Ohara et al., 2007). Emissions of other species, like the biogenic ones, are those usually used in the LMDZ-INCA model and described in Folberth et al. (2006). The error standard deviations assigned to the prior emissions in the matrix $\mathbf{B}$ are set to $100 \%$ of the maximum value of the emission time series during the corresponding year for each grid point, as in Chevallier et al. (2009). This choice of a relatively large value has been made to relax the constraint to the prior emissions. This was found especially important for highly seasonal emissions such as fires. Additional tests are reported in the following using a value of $400 \%$.

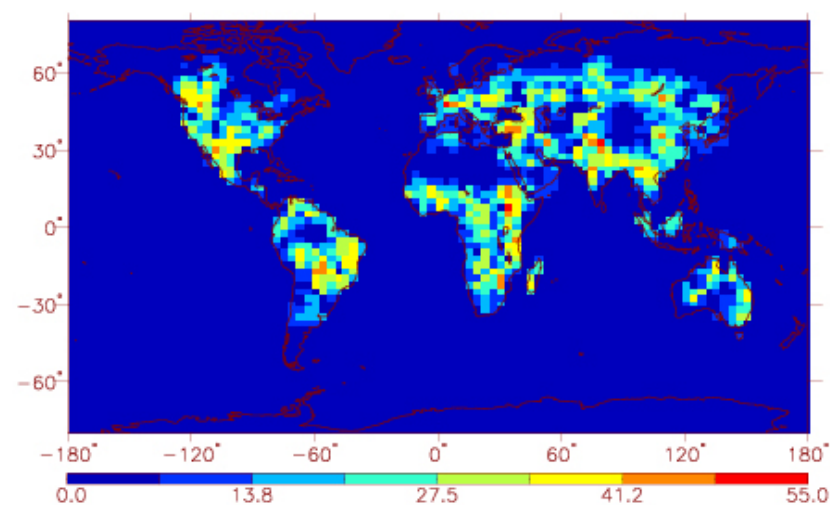

Fig. 3. Reduction of the $\mathrm{CO}$ emissions uncertainty based on the IASI retrievals, in \%, for 8-day mean grid point $\mathrm{CO}$ surface emissions.

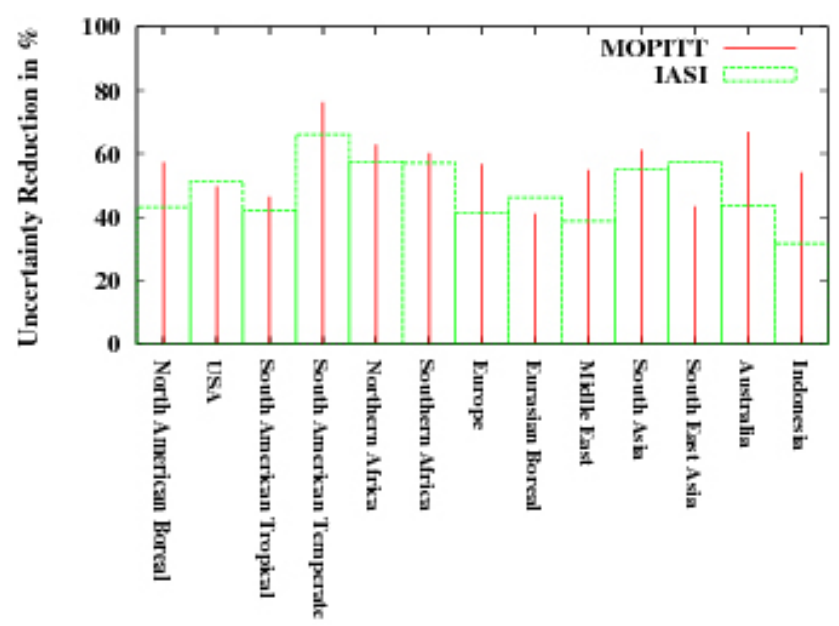

Fig. 4. Comparison of the uncertainty reduction obtained using either IASI or MOPITT retrievals in the 13 aggregation regions, in $\%$.

\subsection{Observation data}

\subsubsection{IASI CO retrievals}

As part of the payload of the METOP-A platform, the IASI interferometer has been flying on a low sun-synchronous polar orbit since October 2006, with equator crossing times of 09:30 and 21:30 LST. Its high spectral resolution allows simultaneous sounding of key meteorological and climate variables in the atmosphere, like temperature or water vapour, while its large swath of about $2200 \mathrm{~km}$ provides near global coverage of the Earth twice a day. Each observation consists of 4 footprints of $12 \mathrm{~km}$ diameter (at nadir), every $50 \mathrm{~km}$ (Clerbaux et al., 2009). The CO products are retrieved from the IASI radiance spectra on a near real time mode (observation $+3 \mathrm{~h}$ ) at LATMOS. The present study makes use of the $\mathrm{CO}$ partial columns products as generated by the latest version of the FORLI-CO (Turquety et al., 2009), a retrieval 


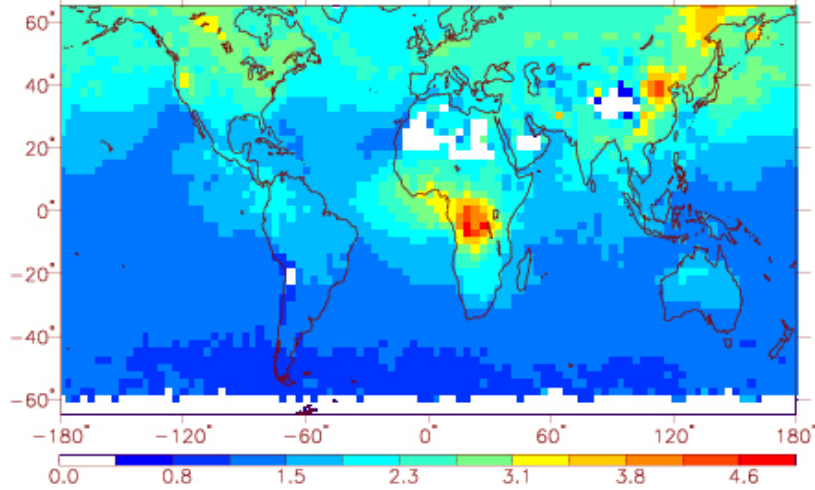

(a) IASI observations

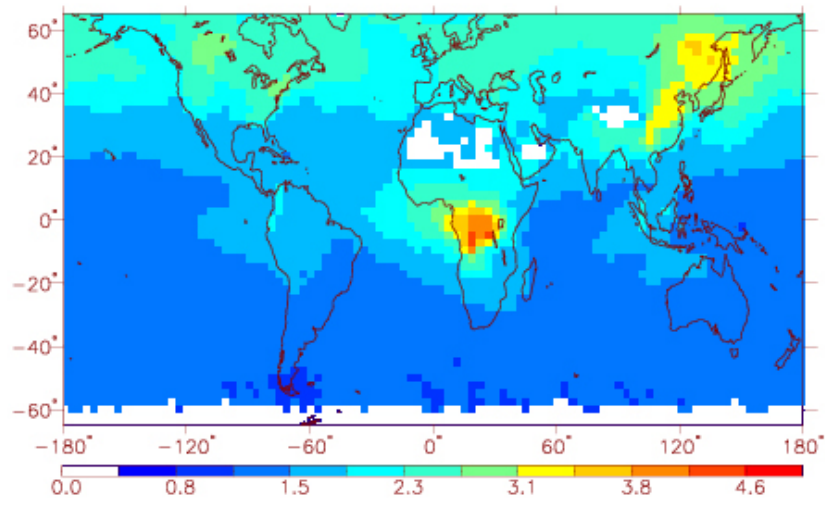

(c) IASI-based posterior simulation

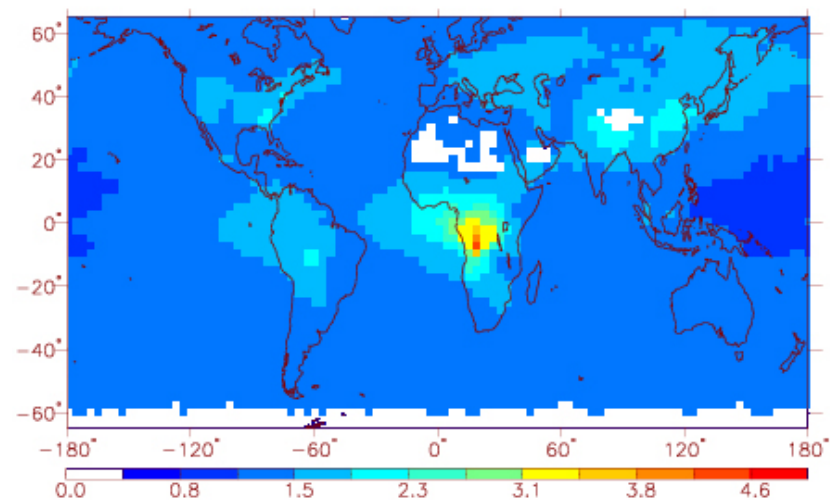

(b) Prior simulation

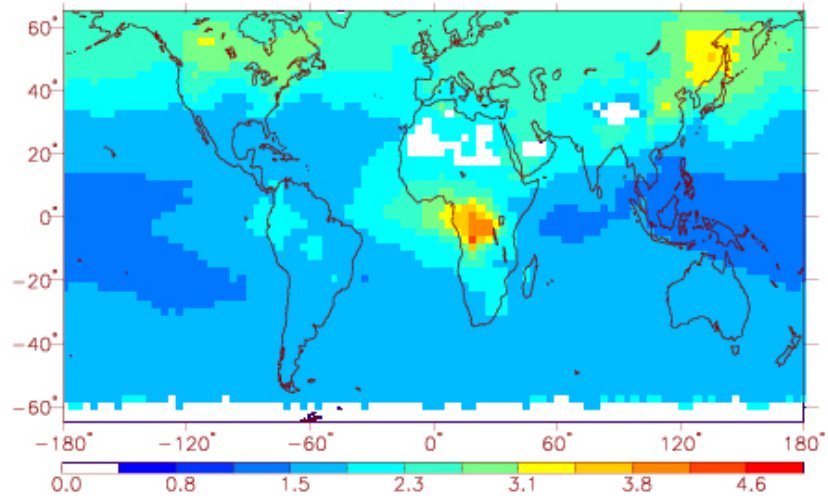

(d) MOPITT-based posterior simulation

Fig. 5. Mean CO partial columns, in $10^{17} \mathrm{~mol} . \mathrm{cm}^{-2}$, for July 2008 in (a) the IASI retrievals for the level closest to $700 \mathrm{hPa}$, (b) the prior simulation, (c) the IASI-based posterior simulation and (d) the MOPITT-based posterior simulation. The simulations all take the individual IASI averaging kernels corresponding to (a) into account. Abscissa and ordinate report the longitudes and latitudes.

code based on optimal estimation. The retrieved profiles are defined on a vertical grid of 19 standard levels (from $0.5 \mathrm{~km}$ to $18.5 \mathrm{~km}$ ) and are provided with individual averaging kernels. CO total column products obtained by this processing algorithm have been validated against other spaceborne thermal infrared measurements (George et al., 2009), including MOPITT. In the continuity of our previous developments for MOPITT (Chevallier et al., 2009), only the layer closest to $700 \mathrm{hPa}$ is used here (see next paragraph). Most cloudy situations are filtered out before the concentration retrieval. Less reliable retrievals have been identified for latitudes within $25^{\circ}$ from the poles, at nightime, and at locations with surface emissivity greater than 0.98 (icy surface) or lower than 0.93 (over desert). Those data are excluded from the inversion.

\subsubsection{MOPITT CO retrievals}

The MOPITT instrument has been flown onboard the NASA EOS-Terra satellite, on another low sun-synchronous orbit that crosses the equator at 10:30 and 22:30 LST. The spatial resolution of its observations is about $22 \mathrm{~km}$ at nadir. Its $640-\mathrm{km}$ swath is smaller than for IASI and three days worth of measurements are needed to achieve global cover- age. MOPITT has been operated nearly continuously since March 2000. Its products (here Version 3 Level product 2) have been made available at NASA Langley Atmospheric Science Data Center. They include CO mixing ratios at 7 standard pressure levels between the surface and $150 \mathrm{hPa}$ for cloud free spots. We use the $700 \mathrm{hPa}$-level CO retrievals as a compromise between closeness to the surface and noise level (Deeter et al., 2003), together with their associated averaging kernels. Following the MOPITT data quality statement (http://web.eos.ucar.edu/mopitt/data/, access: 4 February 2009), only retrievals between $65^{\circ} \mathrm{S}$ and $65^{\circ} \mathrm{N}$ are used, as the weight of the a priori CO profile in the MOPITT retrievals increases towards the pole. Similarly, only the retrievals that are well constrained by the MOPITT radiances (i.e. for which the prior contribution is less than 50\%, (Deeter et al., 2004)) are exploited. Nightime MOPITT observations significantly differ from the daytime ones (due to surface temperature changes) (Crawford et al., 2004; Emmons et al., 2004) and have been left out. 


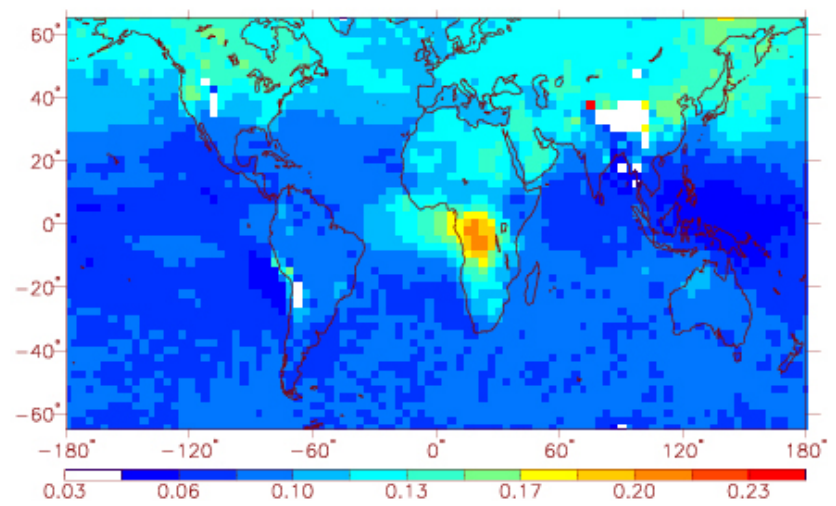

(a) MOPITT observations

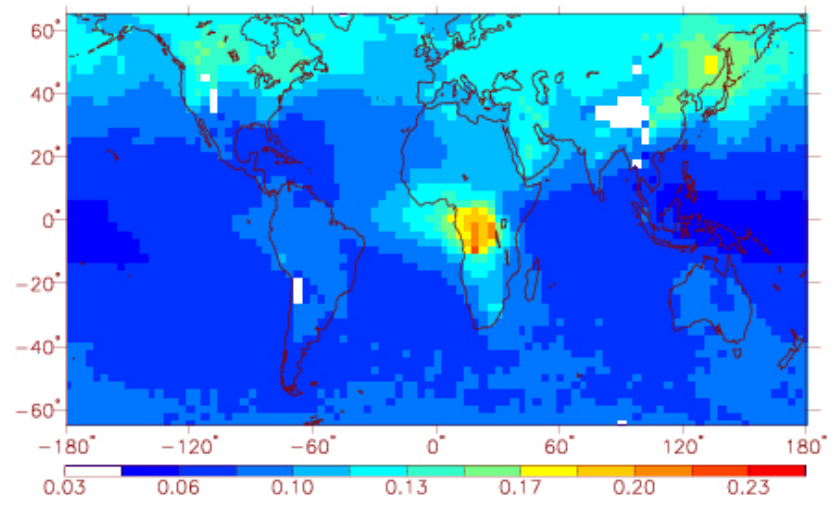

(c) MOPITT-based posterior simulation

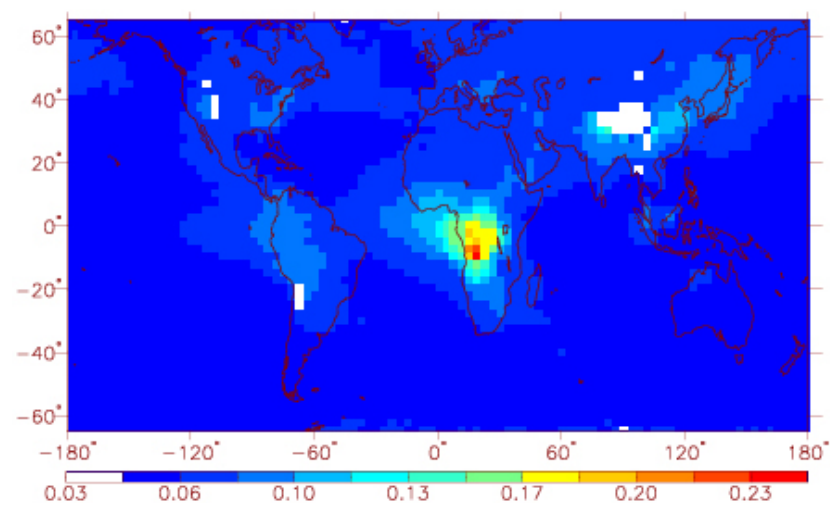

(b) Prior simulation

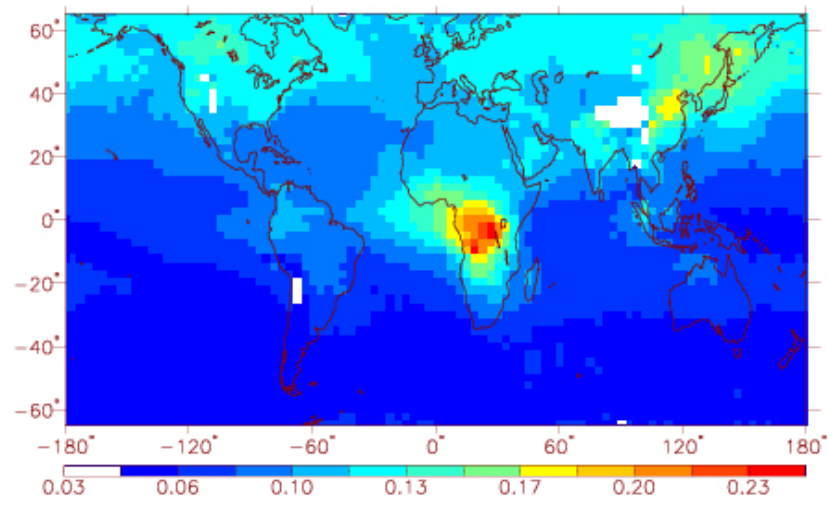

(d) IASI-based posterior simulation

Fig. 6. Mean CO concentrations, in parts per million, for July 2008 in (a) the MOPITT retrievals for the 700 hPa pressure level, (b) the prior simulation, (c) the MOPITT-based posterior simulation and (d) the IASI-based posterior simulation. The simulations all take the individual MOPITT averaging kernels corresponding to (a) into account. Abscissa and ordinate report the longitudes and latitudes.

\subsubsection{Data processing}

Both IASI and MOPITT retrievals are averaged on the CTM resolution $\left(2.5^{\circ} \times 3.75^{\circ}\right)$ at the orbit level in order to reduce the effect of correlated errors between neighbouring observations in the inversion system. About 830000 IASI "super-observations" remain in the 6-month inversion against 545000 "super-observations" for MOPITT, that has a lower spatial coverage. The number of observations is presented in Fig. 2 according to the 13 continental regions of Fig. 1. In comparison, an observing system that would provide one "super-observation" per day on each CTM grid box between $65^{\circ} \mathrm{N}$ and $65^{\circ} \mathrm{S}$ during the same period would have about 913500 "super-observations", which is not much more than the IASI data used here.

As described by Emmons et al. (2004), by Turquety et al. (2009) and by George et al. (2009), and in order to properly compare MOPITT and IASI retrievals $\mathbf{y}$ with the CTM outputs $\mathbf{y}^{\mathrm{CTM}}$, the corresponding averaging kernel matrix $\mathbf{A}$ is used to create a profile $\tilde{\mathbf{y}}$ :

$\tilde{\mathbf{y}}=\mathbf{A} \mathbf{y}^{\mathrm{CTM}}+(\mathbf{I}-\mathbf{A}) \mathbf{y}_{b}$ with $\mathbf{I}$ the identity matrix and $\mathbf{y}_{b}$ the prior concentrations used in the MOPITT (in parts per million) and IASI (in mol.cm ${ }^{-2}$ ) retrievals.

The averaging kernels inform about the sensitivity of the retrievals to the true $\mathrm{CO}$ profile, with the remainder of the information coming from the a priori profile $\mathbf{y}_{\mathbf{b}}$. They are valuable indicators of the vertical resolution of the products (Deeter et al., 2003). In both IASI and MOPITT products, a single prior concentration profile is used for all soundings, while an averaging kernel is provided with each profile.

The errors are assigned in the inversion system as a combination of the retrieval error reported in the MOPITT and IASI datasets, and of the CTM errors arbitrarily set to 50\% of the retrieval values, without correlation.

\section{Results}

\subsection{Uncertainty reduction}

The map of the expected uncertainty reduction on the emissions from IASI is shown in Fig. 3. The uncertainty reduction is defined as $\left(1-\sigma_{a} / \sigma_{b}\right) \times 100$, with $\sigma_{b}$ the prior error 


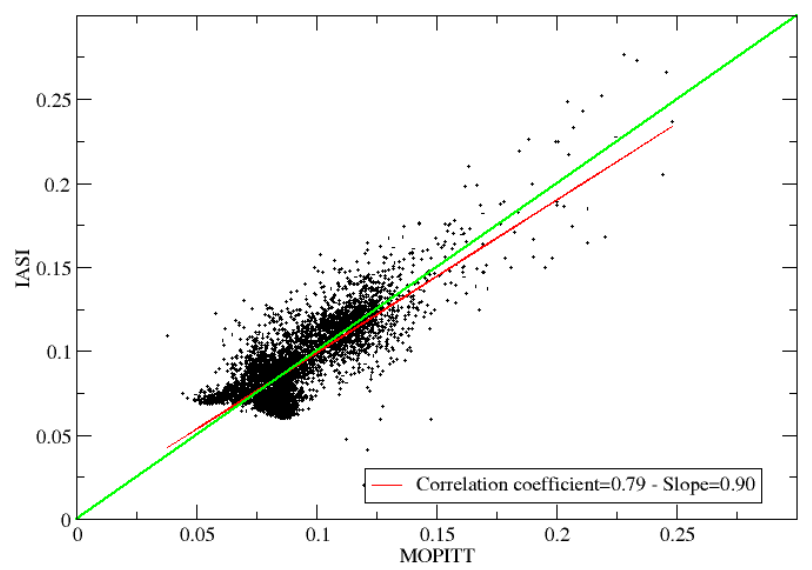

(a) Globe

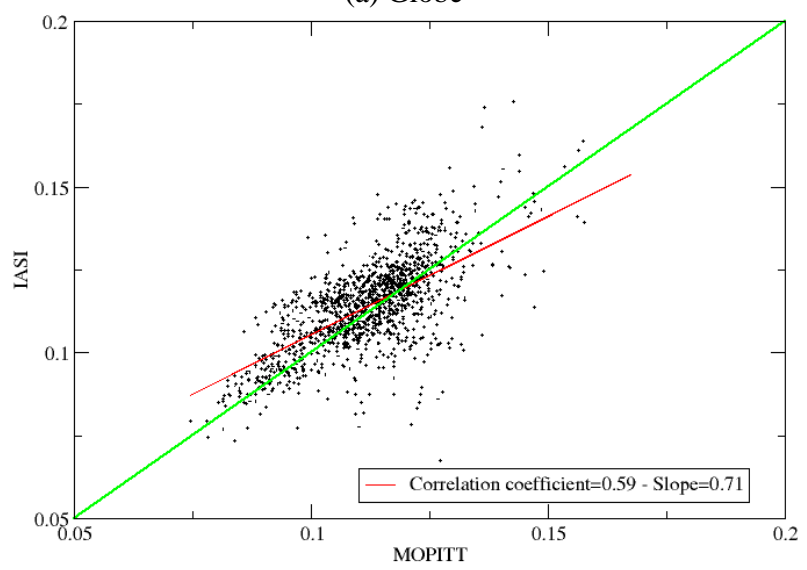

(c) Northern Hemisphere

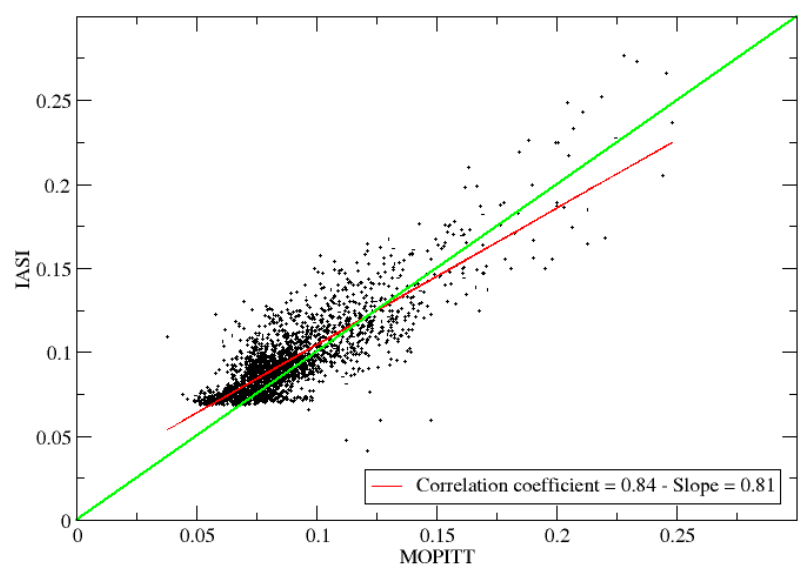

(b) Tropics

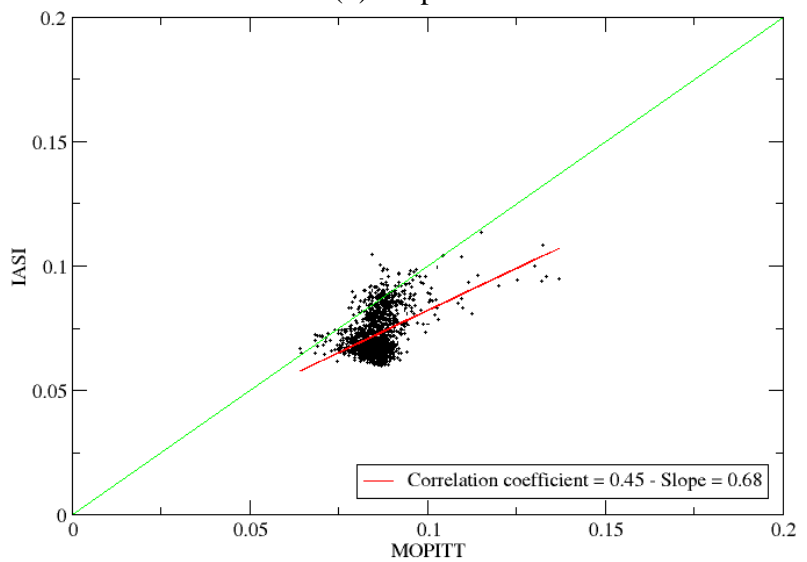

(d) Southern Hemisphere

Fig. 7. Scatter plot of the individual IASI concentration retrievals, in parts per million, vs. the MOPITT ones for August 2008 at the level closest to $700 \mathrm{hPa}$. The correlation coefficient and the regression slope are reported. The bisector appears in green. Note that since the two concentration products have different averaging kernels, full agreement is not expected.

Table 1. CO emission budgets from July to November 2008 before and after the inversions, in Tg. The posterior-minus-prior increments are also given in $\%$ of the prior emissions.

\begin{tabular}{llllll}
\hline & prior (Tg) & $\begin{array}{l}\text { IASI based } \\
\text { posterior (Tg) }\end{array}$ & $\begin{array}{l}\text { IASI } \\
\text { increments(\%) }\end{array}$ & $\begin{array}{l}\text { MOPITT based } \\
\text { posterior (Tg) }\end{array}$ & $\begin{array}{l}\text { MOPITT } \\
\text { increments(\%) }\end{array}$ \\
\hline North Am Boreal & 4 & 16 & $+300 \%$ & 22 & $+450 \%$ \\
USA & 46 & 41 & $-11 \%$ & 48 & $+4 \%$ \\
South Am Trop & 10 & 16 & $+60 \%$ & 7 & $-30 \%$ \\
South Am Temp & 49 & 85 & $+73 \%$ & 94 & $+92 \%$ \\
Northern Africa & 31 & 54 & $+74 \%$ & 50 & $+61 \%$ \\
Southern Africa & 67 & 137 & $+105 \%$ & 125 & $+87 \%$ \\
Europe & 44 & 51 & $+16 \%$ & 64 & $+45 \%$ \\
Eurasian Boreal & 10 & 21 & $+110 \%$ & 29 & $+190 \%$ \\
Middle East & 9 & 15 & $+67 \%$ & 29 & $+222 \%$ \\
South Asia & 32 & 31 & $-3 \%$ & 29 & $-9 \%$ \\
South East Asia & 57 & 103 & $+80 \%$ & 93 & $+63 \%$ \\
Indonesia & 93 & 41 & $-57 \%$ & 9 & $-93 \%$ \\
Australia & 13 & 24 & $+85 \%$ & 41 & $+215 \%$ \\
Globe & 479 & 643 & $+34 \%$ & 649 & $+35 \%$ \\
\hline
\end{tabular}


standard deviation and $\sigma_{a}$ the theoretical posterior error standard deviation (see Sect. 2.1). It is larger than $20 \%$ in the emission regions and reaches $50 \%$ in some isolated pixels.

The uncertainty reductions on the emissions aggregated in the 13 continental regions of Fig. 1 are shown in Fig. 4. In the inversion with IASI retrievals, the uncertainty reduction is maximal in the South American Temperate region (66\%) and minimal in Indonesia (32\%). For instance, significant reductions are seen in Europe (42\%), the USA (52\%) and the two African regions (57\% for both).

The uncertainty reduction with IASI is higher than with MOPITT for two regions (Eurasian Boreal and South East Asia) and similar or smaller by only a few percentage points in most other regions. The largest differences in favor of MOPITT are the less-emitting regions (Australia, Indonesia, Middle East and North American Boreal). As a sensitivity test, the error standard deviation assigned to the prior fluxes has been set to $400 \%$ against $100 \%$ (see Sect. 2.3). The impact on uncertainty is found to be small, with differences in the reduction of a few percents only (not shown).

The reasons for the differences between the uncertainty reductions of IASI and MOPITT are twofold. First, the averaging kernels exhibit significant variability depending on location and time, through variability of the atmospheric temperature profile, surface pressure and temperature, etc. (Deeter et al., 2003). In general, the maximum sensitivities for IASI are observed between 6 and $10 \mathrm{~km}$ (Turquety et al., 2004) whereas MOPITT averaging kernels peak between 4 and $7 \mathrm{~km}$. Second, the number of IASI "super observations" is larger than for MOPITT, as seen in Fig. 2, except over Northern Africa. When IASI and MOPITT provide a similar number of retrievals (e.g., in the Middle East or in Australia), the difference in uncertainty reduction is driven by the difference in averaging kernels, giving an advantage to MOPITT, whose averaging kernels peak at lower altitudes.

\subsection{IASI and MOPITT CO concentrations}

As can be seen in Fig. 5a and Fig. 6a for July 2008, MOPITT and IASI agree in the concentration patterns reasonably well, with high $\mathrm{CO}$ concentrations over Central Africa and East Asia, respectively associated with biomass burning and urban pollution.

The observed IASI (a), prior simulation (b) and IASI posterior simulation (c) $\mathrm{CO}$ concentrations are displayed in Fig. 5 for July 2008. The first-guess concentrations fit the IASI data rather well in the Southern hemisphere. In the Northern hemisphere, an underestimation by about $60 \%$ is seen, and even more over Alaska and East Asia (120\%). A similar feature is seen with MOPITT (Fig. 6). These discrepancies are significantly reduced after the inversion. The model does not exactly fit the observations since the analysis is pulled both towards the observations and towards the prior.

The MOPITT inversion is verified against the IASI concentrations and vice versa with each time the appropriate averaging kernel and space-time location. Comparing both Fig. 5c and d and Fig. $6 c$ and $d$, we can see that the IASI posterior concentrations are smaller than the MOPITT posterior concentrations in the Southern Hemisphere, larger in the plumes over Africa and East Asia (in particular when using the MOPITT averaging kernels that peak lower in the atmosphere than for IASI) and rather similar elsewhere. A summary of the differences between both satellite products is shown in Fig. 7 for the Northern hemisphere, the Southern hemisphere, the Tropics and the whole globe. The patterns of the two retrieval products are consistent to a large extent with a global correlation coefficient of 0.79 . Among the three latitudes bands, the highest correlation (at 0.84) is found in the Tropics (between $30^{\circ} \mathrm{S}$ and $30^{\circ} \mathrm{N}$ ). IASI tends to provide values within a smaller range than MOPITT: the slope varies between 0.68 in the Southern Hemisphere and 0.81 in the Tropics. For the whole globe, the slope reaches 0.90 . These differences are consistent with the study by George et al. (2009) who compared the two level-2 satellite products.

\subsection{Emissions}

The total posterior $\mathrm{CO}$ emissions from July to November 2008 are shown in Table 1. Overall, both inversions lead to an increase of the $\mathrm{CO}$ emissions compared to the corresponding prior, with respectively $+35 \%$ with MOPITT and $+34 \%$ with IASI for the whole Earth. Both inversions yield analysis increments (posterior minus prior) of the same sign, except for the USA and the South American Tropical region, where the increments do not exceed a few Tg anyway. An important increase is observed in Southern Africa, a region which is affected by biomass burning ( $+87 \%$ with MOPITT and $+105 \%$ with IASI) and for South East Asia (+63\% with MOPITT and $+80 \%$ with IASI) as already noted in other studies (Carmichael et al., 2003; Palmer et al., 2003; Pétron et al., 2004; Arellano et al., 2004; Allen et al., 2004; Heald et al., 2004; Wang et al., 2004). These two regions are the largest emitters of $\mathrm{CO}$ among the 13 regions defined, in the MOPITT and IASI analyses, with respectively 125 and $137 \mathrm{Tg}$ for Southern Africa, and 93 and 103 Tg for South East Asia. Positive increments are also seen in the regions North American Boreal, South American temperate, Northen Africa, Europe, Eurasian Boreal, Middle East, South Asia and Australia. Posterior emissions are lower than the prior estimates in Indonesia, likely because the prior biomass burning inventory corresponds to an ENSO year (2006) (-93\% with MOPITT and $-57 \%$ with IASI).

The analysed total emissions with IASI differ by less than $1 \%$ from MOPITT (643 against $649 \mathrm{Tg}$ ).

\section{Conclusions}

This paper shows the first comparison between inversions of $\mathrm{CO}$ emissions using IASI and MOPITT retrievals of $\mathrm{CO}$ 
concentrations at about $700 \mathrm{hPa}$. IASI and MOPITT global concentration patterns are similar, but IASI retrievals tend to show smaller concentrations in the Southern Hemisphere and larger ones in the plumes over Africa and East Asia. The global CO emissions from July to November 2008 found with IASI ( $643 \mathrm{Tg})$ is very similar to the one found with MOPITT (649 Tg). The theoretical computations shown here indicate that, in principle, the IASI inverted emissions should be nearly as reliable as with MOPITT, thanks to its large data density and in spite of lesser sensitivity in the lower troposphere than MOPITT.

To date, relatively limited experience has been gathered with IASI CO retrievals, in particular in comparison with the well-documented MOPITT 9-year database. Only a few months worth of IASI data were available for this study. Moreover, the fact that they correspond to recent dates prevented us from benefitting from surface measurements to rate the inversions. In spite of these limitations, the preliminary results gathered here show good promises for IASI to help pinning down the $\mathrm{CO}$ emissions.

A multi-instrument inversion strategy may filter the product-specific biases of the retrievals, with the inversion providing concentration values somewhere in-between the retrieval products. However, some biases may be shared by the two instruments, like the possible underestimation of very large concentrations (e.g., in fire plumes) caused by the use of a single prior profile in both concentrations products. Some improvements of the inversion results are also expected from the inclusion of formaldehyde retrievals, like those from the Ozone Monitoring Instrument (OMI) (Levelt et al., 2006). Indeed, observations of HCHO should indirectly constrain the emissions in the inversion system by informing about the secondary production of $\mathrm{CO}$.

Acknowledgements. IASI has been developed and built under the responsibility of the Centre National d'Etudes Spatiales (CNES, France). It is flown onboard the Metop satellites as part of the EUMETSAT Polar System. The IASI L1 data are received through the EUMETCast near real time data distribution service. We acknowledge the NCAR Science team for MOPITT data. The autors acknowledge the Ether French atmospheric database (http://ether.ipsl.jussieu.fr) and LATMOS for providing the IASI data. Authors wish to thank F. Marabelle (LSCE) for computer support. The first author is funded by CNES.

Edited by: A. Richter

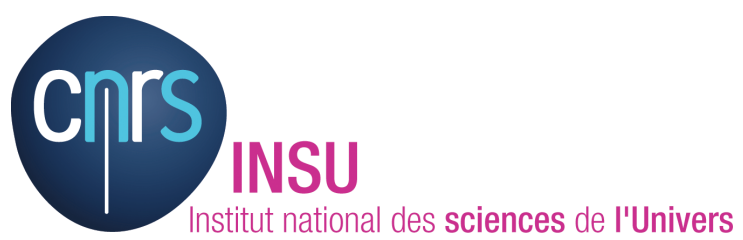

The publication of this article is financed by CNRS-INSU.

\section{References}

Allen,D., Pickering, K., and Fox-Rabinovitz, M. : Evaluation of pollutant outflow and $\mathrm{CO}$ sources during TRACE-P using model-calculated, aircraft-based, and measurements of MOPITT-derived CO concentrations, J. Geophys. Res., 109, D15S03, doi:10.1029/2003JD004250, 2004.

Arellano Jr., A. F., Kasibhatla, P. S., Giglio, L., van der Werf, G. R., and Randerson, J. T.: Top-down estimates of global CO sources using MOPITT measurements, Geophys. Res. Lett., 31, L01104, doi:10.1029/2003GL018609, 2004.

Bousquet, P., Hauglustaine, D. A., Peylin, P., Carouge, C., and Ciais, P.: Two decades of $\mathrm{OH}$ variability as inferred by an inversion of atmospheric transport and chemistry of methyl chloroform, Atmos. Chem. Phys., 5, 2635-2656, 2005, http://www.atmos-chem-phys.net/5/2635/2005/.

Buchwitz, M., Khlystova, I., Bovensmann, H., and Burrows, J. P.: Three years of global carbon monoxide from SCIAMACHY: Comparison with MOPITT and first results related to the detection of enhanced CO over cities, Atmos. Chem. Phys., 7, 23992411,2007.

Carmichael, G. R., Tang, Y., Kurata, G., Uno, I., and Streets, D. G.: Evaluating regional emissions estimates using the TRACE-P observations, J.Geophys. Res., 108(D21), 8810, doi:10.1029/2002JD003116, 2003.

Chevallier, F., Fisher, M., Peylin, P., Serrar, S., Bousquet, P., Bréon, F.-M., Chédin, A., and Ciais, P.: Inferring $\mathrm{CO}_{2}$ sources and sinks from satellite observations: method and application to TOVS data, J. Geophys. Res., 110, D24309, doi:10.1029/2005JD006390, 2005.

Chevallier, F., Bréon, F.-M., and Rayner, P. J.: Contribution of the Orbiting Carbon Observatory to the estimation of $\mathrm{CO}_{2}$ sources and sinks: Theoretical study in a variational data assimilation framework, J. Geophys. Res., 112, D09307, doi:10.1029/2006JD007375, 2007.

Chevallier, F., Fortems, A., Bousquet, P., Pison, I., Szopa, S., Devaux, M., and Hauglustaine, D.: African CO emissions between years 2000 to 2006 as estimated from MOPITT observations, Biogeosciences, 6, 103-111, 2009, http://www.biogeosciences.net/6/103/2009/.

Clerbaux, C., Coheur, P.-F., Hurtmans, D., Barret, B., Carleel, M., Colin, R., Semeniuk, K., McConnell, J.C., Boone, C. and Bernath, P.: Carbon monoxide distribution from the ACEFTS solar occultation measurements, Geophys. Res. Lett., 32, L16S01, doi:10.1029/2005GL022394, 2005.

Clerbaux, C., Edwards, D. P., Deeter, M., Emmons, L., Lamraque, J.-F., Tie, X. X., Massie, S. T., and Gille, J.: Carbon monoxide pollution from cities and urban areas observed by the Terra/MOPITT mission, Geophys. Res. Lett., 35, L103817, doi:10.1029/2007GL032300, 2008.

Clerbaux, C., Boynard, A., Clarisse, L., George, M., Hadji-Lazaro, J., Herbin, H., Hurtmans, D., Pommier, M., Razavi, A., Turquety, S., Wespes, C., and Coheur, P.-F.: Monitoring of atmospheric composition using the thermal infrared IASI/MetOp sounder, Atmos. Chem. Phys., 9, 6041-6054, 2009,

http://www.atmos-chem-phys.net/9/6041/2009/.

Crawford, J. H., Heald, C. L., Fuelberg, H. E., Morse, D. M., Sachse, G. W., Emmons, L. K., Gille, J. C., Edward, D. P., Deeter, M. N., Chen, G., Olson, J. R., Connors, V. S., Kittaka, C., and Hamlin, A. J.: Relationship between measurements of MO- 
PITT and in-situ observations of CO based on a large-scale feature sampled during TRACE-P, J.Geophys. Res., 109, D15S04, doi:10.1029/2002JD004308, 2004.

Deeter, M. N., Emmons, L. K., Francis, G. L., et al.: Operational carbon monoxide retrieval algorithm and selected results for the MOPITT instrument, J. Geophys. Res., 108(D14), 4399, doi:10.1029/2002JD003186, 2003.

Deeter, M. N., Emmons, L. K., Edwards, D. P., Gille, J. C., and Drummond, J. R.: Vertical resolution and information content of CO profiles retrieved by MOPITT, Geophys. Res. Lett., 31, L15112, doi:10.1029/2004GL020235, 2004.

Emmons, L. K., Deeter, M. N., Gille, J. C., et al.: Validation of Measurements of Pollution in the Troposphere (MOPITT) CO retrievals with aircraft in situ profiles, J. Geophys. Res., 109, D03309, doi:10.1029/2003JD004101, 2004.

Folberth, G. A., Hauglustaine, D. A., Lathière, J., and Brocheto, F.: Interactive chemistry in the Laboratoire de Météorologie Dynamique general circulation model: model description and impact analysis of biogenic hydrocarbons on tropospheric chemistry, Atmos. Chem. Phys., 6, 2273-2319, 2006,

http://www.atmos-chem-phys.net/6/2273/2006/.

George, M., Clerbaux, C., Coheur, P.-F., Hadji-Lazaro, J., Edwards, D., Worden, H., Luo, M., Rinsland, C. P., and Barnet, C.: Carbon monoxide distributions from the IASI/METOP mission: evaluation with other space-borne remote sensors, Atmos. Chem. Phys. Discuss., 9, 9793-9822, 2009,

http://www.atmos-chem-phys-discuss.net/9/9793/2009/.

Gilbert, J. C. and Lemaréchal, C.: Some numerical experiments with variable-storage quasi-Newton algorithms, Math. Program., 45, 407-435, 1989.

Hauglustaine, D. A., Hourdin, F., Jourdain, L., Filiberti, M.-A., Walters, S., Lamarque, J.-F., and Holland, E. A.: Interactive chemistry in the Laboratoire de Météorologie Dynamique general circulation model: Description and background tropospheric chemistry evaluation, J. Geophys. Res., 109, D04314, doi:10.1029/2003JD003957, 2004.

Heald, C. L., Jacob, D. J., Jones, D. B. A., Palmer, P. I., Logan, J. A., Streets, D. G., Sachse, G. W., Gille, J. C., Hoffman, R. N., and Nehrkorn, T.: Comparative inverse analysis of satellite (MOPITT) and aircraft (TRACE-P) observations to estimates Asian sources of carbon monoxide, J. Geophys. Res., 109, D23306, doi:10.1029/2004GL005185, 2004.

Hollingsworth, A., Engelen, R. J., Textor, C., et al.: The Global Earth-system Monitoring using Satellite and in-situ data (GEMS) Project: Towards a monitoring and forecasting system for atmospheric composition, B. Am. Meteorol. Soc., 89, 1147-1164, doi:10.1175/2008BAMMS2355.1, 2008.

Hourdin, F., Musat, I., Bony, S., et al.: The LMDZ4 general circulation model: climate performance and sensitivity to parametrized physics with emphasis on tropical convection, Clim. Dynam., 27, 787-813, 2006.

Levelt, P. F., Hilsenrath, E., Leppelmeier, G. W., van den Oord, G. H. J., Bhartia, P. K., Tamminen, J., de Haan, J. F., and Veefkinf, J. P.: Science objectives of the Ozone Monitoring Instrument, Geo. Rem. Sens., 44, 5, 1199-1208, 2006.

Luo, M., Rinsland, C. P., Rodgers, C. D., Logan, J. A., Worden, H., Kulawik, S., Eldering, A., Goldman, A., Shephard, M. W., Gunson, M., and Lampel, M. : Comparison of carbon monoxide measurements by TES and MOPITT: The influ- ence of a priori data and instrument characteristics on nadir atmospheric species retrievals, J. Geophys. Res., 112, D09303, doi:10.1029/2006JD007663, 2007.

Ohara, T., Akimoto, H., Kurokawa, J., Horii, N., Yamaji, K., Yan, X., and Hayasaka, T.: An Asian emission inventory of anthropogenic emission sources for the period 1980-2020, Atmos. Chem. Phys., 7, 4419-4444, 2007,

http://www.atmos-chem-phys.net/7/4419/2007/.

Olivier, J. G. J. and Berdowski, J. J. M.: Global emissions sources and sinks, The Climate System, 2001.

Palmer, P. I., Jacob, D. J., Jones, D. B. A., Heald, C. L., Yantosca, R. M., Logan, J. A., Sachse, G.W. and Streets, D.G. : Inverting for emissions of carbon monoxide from Asia using aircraft observations over the Western Pacific, J. Geophys. Res., 108(D21), 8828, doi:10.1029/2003JD003397, 2007.

Pétron, G., Granier, C., Khattatov, B., Yudin, V., Lamarque, J.-F., Emmons, L., Gille, J., and Edwards, D. P.: Monthly CO surface sources inventory based on the 20002001 MOPITT satellite data, Geophys. Res. Lett., 31, L21107, doi:10.1029/2004GL020560, 2004.

Pfister, G., Hess, P. G., Emmons, L. K., Lamarque, J.-F., Wiedinmyer, C., Edwards, D. P., Petron, G., Gille, J. C., and Sachse, G. W.: Quantifying CO emissions from the 2004 Alaskan wildfires using MOPITT CO data, Geophys. Res. Lett, 32, L11809, doi:10.1029/2004GL022995, 2004.

Pison, I., Bousquet, P., Chevallier, F., Szopa, S., and Hauglustaine, D. A.: Multi-species inversion of $\mathrm{CH}_{4}, \mathrm{CO}$ and $\mathrm{H}_{2}$ emissions from surface measurements, Atmos. Chem. Phys., 9, 5281-5297, 2009 ,

http://www.atmos-chem-phys.net/9/5281/2009/.

Rodgers, C. D. and Connor, B. J.: Intercomparison of remote sounding instruments, J. Geophys. Res., 108(D3), 4116, doi:10.1029/2002JD002299, 2003.

Turquety, S., Hadji-Lazaro, J., Clerbaux, C., Hauglustaine, D. A., Clough, S. A., Cassé, V., Schlüssel, P., and Mégie, G.: Operational trace gas retrieval algorithm for the Infrared Atmospheric Sounding Interferometer, J. Geophys. Res., 109, D21301, doi:10.1029/2004JD004821, 2004.

Turquety, S., Logan, J. A., Jacob, D. J., Hudman, R. C., Leung, F. Y., Heald, C. L., Yantosca, R. M., and Wu, S.: Inventory of boreal fire emissions for North America in 2004: importance of peat burning and pyroconvective injection, J. Geophys. Res., 112, D12S03, doi:10.1029/2006JD007281, 2007.

Turquety, S., Hurtmans, D., Hadji-Lazaro, J., Coheur, P.-F., Clerbaux, C., Josset, D., and Tsamalis, C.: Tracking the emission and transport of pollution from wildfires using the IASI CO retrievals: analysis of the summer 2007 Greek fires, Atmos. Chem. Phys., 9, 4897-4913, 2009,

http://www.atmos-chem-phys.net/9/4897/2009/.

Van der Werf, G. R., Randerson, J. T., Giglio, L., Collatz, G. J., and Kasibhatla, P. S.: Interannual variability in global biomass burning emission from 1997 to 2004, Atmos. Chem. Phys., 6, 3423-3441, 2006, http://www.atmos-chem-phys.net/6/3423/2006/.

Wang, Y. X., McElroy, M. B., Wang, T., and Palmer, P. I.: Asian emissions of $\mathrm{CO}$ and NOx : constraints from aircraft and Chinese station data, J. Geophys. Res., 109, D24304, doi:10.1029/2004JD005250, 2004. 